\title{
UPAYA GURU PENJAS DALAM MENDETEKSI GANGGUAN PERSEPTUAL MOTORIK PADA SISWA SEKOLAH DASAR
}

\author{
Oleh: Yudanto
}

Dosen Jurusan Pendidikan Olahraga FIK-UNY

\begin{abstract}
Abstrak
Pendidikan Jasmani merupakan proses belajar untuk gerak dan belajar untuk bergerak. Program pendidikan jasmani di sekolah dasar pada dasarnya berisi tentang program perseptual motorik.

Perseptual motorik merupakan kemampuan individu dalam menerima, menginterpretasikan dan memberikan reaksi dengan tepat kepada rangsang yang datang. Perseptual motorik terdiri atas beberapa unsur, diantaranya: kesadaran tubuh, kesadaran arah, kesadaran ruang, dan kesadaran tempo. Perseptual motorik sangat berpengaruh dalam prestasi akademik siswa.

Perkembangan kemampuan perseptual motorik hendaknya diperhatikan dan dipantau oleh guru Penjas. Mendeteksi gangguan perseptual motorik anak sejak awal harus dilakukan oleh guru Penjas. Mendeteksi gangguan perseptual motorik dapat dilakuan dengan sebuah tes perseptual motorik, salah satu tes untuk mengetahui gangguan peseptual motorik adalah tes perseptual motorik dari Claudine Sherill (1993: 324-325). Tes ini meliputi: mengidentifikasi atau mengenali bagian tubuh, menyentuh kanan-kiri bagian anggota badan yang berlawanan, mengubah (berubah) posisi dalam suatu ruang, melintasi garis tengah, meniru gerakan, meniru gerakan olahraga, jejak visual (visual tracking), keseimbangan statis, keseimbangan dinamis, dan dominasi lateral.
\end{abstract}

Kata Kunci: deteksi, gangguan perseptual motorik, siswa sekolah dasar

Pendidikan merupakan salah satu faktor utama dalam pelaksanaan pendidikan nasional, terutama dalam mempersiapkan sumber daya manusia yang tangguh. Sesuai dengan visi pembangunan nasional, pada dasarnya berdasarkan paradigma pembangunan manusia seutuhnya yang meletakkan manusia sebagai subjek yang memiliki potensi untuk mengaktualisasikan potensi dirinya secara optimal. Berkaitan dengan itu, pendidikan 
diarahkan untuk mengembangkan kecerdasan secara komprehensif, yaitu kecerdasan otak kiri yang lebih dikenal kecerdasan intelektual (kemampuan kognitif), kecerdasan otak kanan yang akhir-akhir ini lebih dikenal dengan kecerdasan spiritual, sosial, emosional, estetis dan kinestetis (kemampuan afektif dan psikomotorik).

Mata pelajaran Pendidikan Jasmani, Olahraga dan Kesehatan termasuk salah satu upaya untuk mewujudkan manusia seutuhnya yang diselenggarakan di sekolah, baik dari jenjang pendidikan dasar sampai menengah. Pendidikan Jasmani, Olahraga dan Kesehatan merupakan bagian integral dari pendidikan secara keseluruhan, yang bertujuan untuk mengembangkan aspek kebugaran jasmani, keterampilan gerak, keterampilan berpikir kritis, keterampilan sosial, penalaran, stabilitas emosional, tindakan moral, aspek pola hidup sehat dan pengenalan lingkungan bersih melalui aktivitas jasmani, olahraga dan kesehatan terpilih yang direncanakan secara sistematis dalam rangka mencapai tujuan pendidikan nasional. Pendidikan sebagai suatu proses pembinaan manusia yang berlangsung seumur hidup, Pendidikan Jasmani, Olahraga dan Kesehatan yang diajarkan di sekolah memiliki peranan sangat penting, yaitu memberikan kesempatan kepada peserta didik untuk terlibat langsung dalam berbagai pengalaman belajar melalui aktivitas jasmani, olahraga dan kesehatan yang dilakukan secara sistematis. Pembekalan pengalaman belajar itu diarahkan untuk membina pertumbuhan fisik dan pengembangan psikis yang lebih baik, sekaligus membentuk pola hidup sehat dan bugar sepanjang hayat.

Menurut BSNP (2006: 703) pelaksanaan Pendidikan Jasmani, Olahraga dan Kesehatan di Sekolah Dasar, bertujuan agar peserta didik memiliki kemampuan sebagai berikut: (1) mengembangakan keterampilan pengelolaan diri dalam upaya pengembangan dan pemeliharaan kebugaran jasmani serta pola hidup sehat melalui berbagai aktivitas jasmani dan olahraga terpilih, (2) meningkatkan pertumbuhan fisik dan pengembangan psikis yang lebih baik, (3) meningkatkan kemampuan dan keterampilan gerak dasar, (4) meletakkan landasan karakter moral yang kuat melalui internalisasi nilai-nilai yang terkandung di dalam Pendidikan Jasmani, Olahraga dan Kesehatan, (5) mengembangkan sikap sportif jujur, disiplin, bertanggung jawab, kerjasama, percaya diri dan demokratis, (6) mengembangkan keterampilan untuk menjaga keselamatan diri sendiri, orang lain dan lingkungan, dan (7) memahami konsep aktivitas jasmani dan olahraga di lingkungan yang bersih sebagai informasi untuk mencapai pertumbuhan fisik yang sempurna, pola hidup sehat dan kebugaran, terampil serta memiliki sikap yang positif.

Pengembangan gerak merupakan salah satu bagian dari tujuan dalam pelaksanaan pembelajaran pendidikan jasmani. Perseptual motorik merupakan salah satu gerak yang perlu mendapatkan perhatian bagi siswa di sekolah dasar. Pada dasarnya perseptual motorik merupakan kemampuan individu untuk menerima, menginterpretasikan dan memberikan reaksi dengan tepat kepada sejumlah rangsangan yang datang kepadanya, tidak hanya dari luar dirinya tetapi juga dari dalam. Menurut Yudha M. Saputra (2001: 22) perseptual motorik sering juga dijelaskan sebagai hubungan antara gerak dan persepsi. Persepsi adalah proses penerimaan, pemilihan dan pemahaman informasi atau rangsang 
dari luar. Persepsi menghasilkan kesadaran tentang yang sedang terjadi di luar tubuh kita dan merupakan kemampuan kita untuk menerima informasi melalui penginderaan.

Program pendidikan jasmani di sekolah dasar pada dasarnya berisi tentang program perseptual motorik. Perseptual motorik tercakup dalam program pendidikan jasmani. Program pendidikan jasmani berbeda dengan program perseptual motorik. Tujuan program pendidikan jasmani itu sendiri berisfat menyeluruh atau majemuk, sementara tujuan program perseptual motorik relatif sempit tertuju pada kemampuan kognitif, (Yudha M. Saputra, 2001: 22). Guru pendidikan jasmani di sekolah dasar memiliki tugas dan peran dalam memahami dan mengetahui perseptual motorik siswanya. Upaya guru pendidikan jasmani dalam mengenali gangguan perseptual motorik siswa harus dilakukan. Hal ini akan bermanfaat dalam menentukan aktivitas yang harus dilakukan oleh siswa, sesuai dengan kemampuan atau tahap pertumbuhan dan perkembanngannya. Untuk itu, tulisan ini akan menguraikan tentang upaya dalam mengenali gangguan perseptual motorik bagi siswa sekolah dasar.

\section{HAKIKAT PERSEPTUAL MOTORIK}

Perseptual motorik pada dasarnya merujuk pada aktivitas yang dilakukan dengan maksud meningkatkan kognitif dan kemampuan akademik. Menurut Sugiyanto (2007: 85) perseptual motorik adalah kemampuan menginterpretasi stimulus yang diterima oleh organ indera. Kemampuan perseptual berguna untuk memahami segala sesuatu yang ada di sekitar, sehingga seseorang mampu berbuat atau melakukan tindakan tertentu sesuai dengan situasi yang dihadapi. Misalnya ketika seseorang sedang bermain bola, ia dapat melihat bola dan memahami situasi bola, sehingga ia dapat memainkan bola sesuai dengan situasi.

Rusli Lutan (2001: 78) menyatakan bahwa kualitas gerak seseorang bergantung pada perseptual motorik. Berkaitan dengan hal tersebut, dalam pemberian atau contoh pelaksanaan tugas gerak, kemampuan anak untuk melakukan tugas yang dimaksud, bergantung pada kemampuannya memperoleh informasi dan menafsirkan makna informasi tersebut. Kemampuan menangkap informasi serta menafsirkan dengan cermat, maka pelaksanaan gerak yang serasi akan lebih bagus daripada kemampuan perseptual motorik yang kurang cermat. Perseptual motorik adalah sebuah proses pengorganisasian, penataan informasi yang diperoleh dan kemudian disimpan, untuk kemudian menghasilkan reaksi berupa pola gerak. Lebih lanjut dapat dikatakan bahwa perseptual motorik merupakan sebuah proses perolehan dan peningkatan keterampilan dan kemampuan untuk berfungsi.

\section{PROSES PERSEPTUAL MOTORIK}

Proses terjadinya perseptual motorik melewati beberapa tahapan, yang meliputi: masuknya rangsang melalui saraf sensoris, perpaduan rangsang, penafsiran gerak, pengaktifan gerak, dan umpan balik. Proses terjadinya perseptual motorik dapat digambarkan dalam bagan berikut ini 


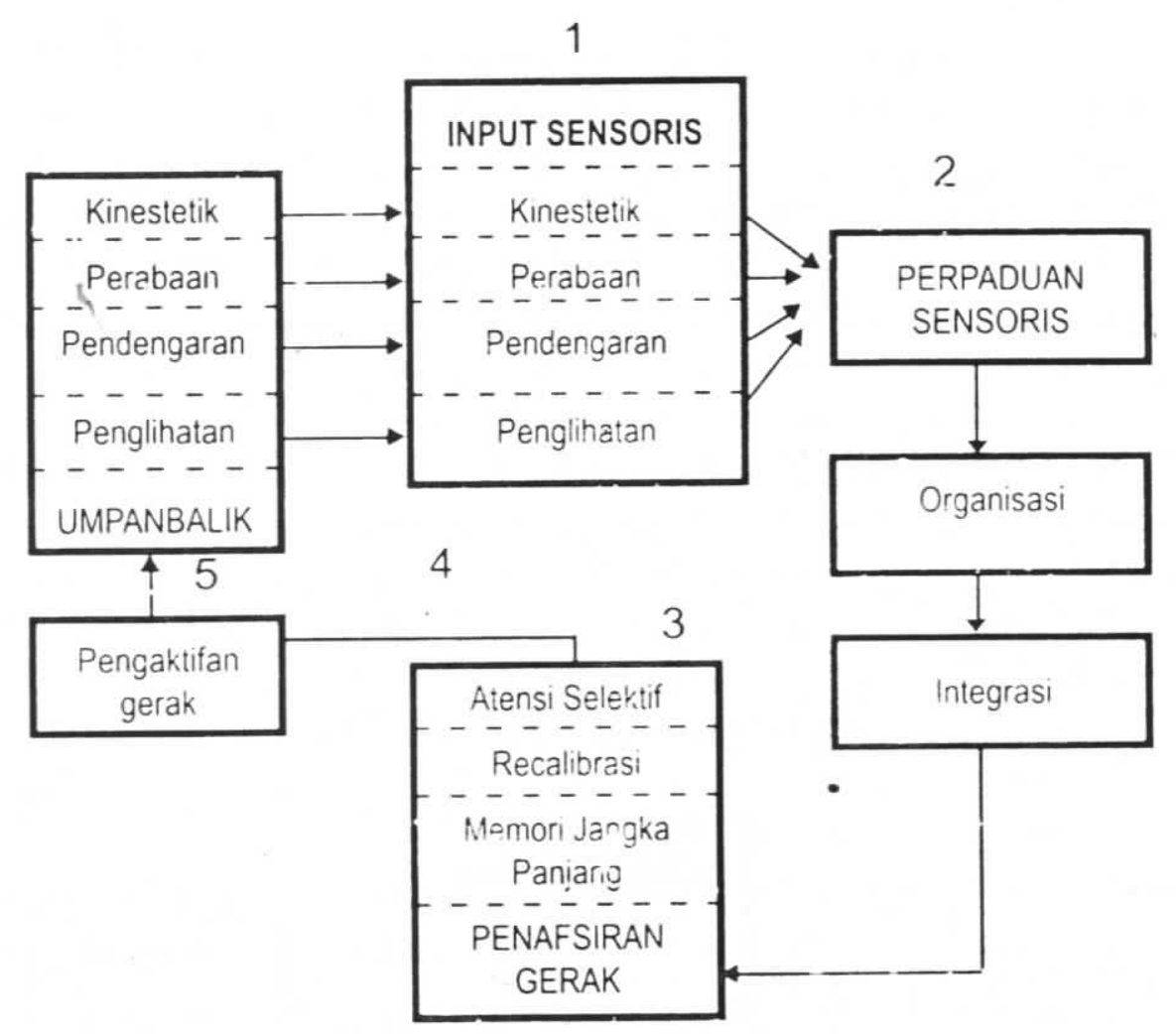

Gambar 1. Proses Terjadinya Perseptual Motorik

Gambar di atas merupakan proses terjadinya perseptual motorik, dari gambar di atas dapat dijelaskan mengenai proses terjadinya perseptual motorik sebagai berikut:

1. Masukan rangsang melalui saraf sensoris: aneka rangsangan yang telah ditangkap melalui saraf sensoris, seperti: penglihatan, pendengaran, perabaan, dan kinestetis. Rangsang yang telah diterima itu kemudian diteruskan ke dalam otak dalam bentuk pola energi saraf.

2. Perpaduan rangsang: rangsang yang telah diperoleh kemudian dipadukan atau disimpan bersama-sama dengan rangsang yang pernah diperoleh dan disimpan dalam memori.

3. Penafsiran gerak: berdasarkan pemahaman rangsang yang telah diterima, maka akan diputuskan pola gerak. Respon ini merupakan jawaban terhadap kombinasi antara rangsang yang diterima dan informasi yang tersimpan dalam memori.

4. Pengaktifan gerak: pada tahap ini merupakan terjadinya gerak yang sesungguhnya dilaksanakan. Gerak ini dapat diamati.

5. Umpan balik: pada tahap ini merupakan evaluasi gerak yang dilaksanakan melalui berbagai alat indra, yang selanjutnya informasi umpan balik itu, diteruskan ke beberapa sumber masukan informasi, seperti: dari pengamatan atau perasaan. Tahap selanjutnya adalah pelaksanaan gerak sesuai dengan koreksi yang diperoleh. 


\section{UNSUR-UNSUR PERSEPTUAL MOTORIK}

Unsur-unsur perseptual motorik terdiri atas berbagai unsur, diantaranya: kesadaran tubuh, kesadaran ruang, kesadaran arah dan kesadaran tempo, (Rusli Lutan: 2001: 8). Berikut ini adalah penjelasan dari berbagai unsur perseptual motorik:

1. Kesadaran tubuh.

Kesadaran tubbuh merupakan kesanggupan untuk mengenali bagian-bagian tubuh dan manfaatnya bagi gerak. Kesadaran tubuh memiliki tiga kesadaran yang terkait dengan aspek pengetahuan tubuh, pengetahuan tentang apa yang dapat dilakukan bagian tubuh, dan pengetahuan tentang bagaimana bagian itu berfungsi. Contoh gerakan:

a. Menyentuh anggota bagian tubuh satu per satu yang telah disebutkan oleh guru, serta menyebutkan fungsi anggota tubuh tersebut.

b. Menyentuh anggota tubuh bagian kiri dengan menggunakan tangan kanan, yang telah disebutkan oleh guru, serta menyebutkan fungsi anggota tubuh tersebut.

2. Kedaran ruang

Kesadaran ruang merupakan kemampuan untuk menyesuaikan diri pada posisi di antara orang lain dan objek lain dalam suatu ruang atau tempat, juga merupakan kemampuan untuk mengetahui seberapa luas ruang atau tempat yang digunakan tubuh pada saat bergerak. Contoh gerakan:

a. Berjalan di dalam lingkaran dengan teman-teman, jangan sampai bertabrakan.

b. Berlari zig-zag melewati beberapa pancang.

c. Menaiki tangga.

3. Kesadaran arah.

Kesadaran arah merupakan pemahaman tubuh yang berkenaan dengan tempat dan arah, terdiri atas dua komponen pemahaman yaitu: (1) pemahaman internal untuk dapat menggerakkan tubuh ke samping kanan dan samping kiri (laterality), dan (2) proyeksi eksternal dari laterality, komponen ini merupakan pamahaman yang memberikan dimensi ruang. Anak yang mempunyai kemampuan ini, mampu melaksanakan konsep gerak kanan-kiri, atas-bawah, depan-belakang, dan berbagai kombinasi gerak lainnya. Contoh gerakan:

a. Bergeser ke kanan atau ke kiri, sesuai dengan perintah guru.

b. Melangkah ke depan beberapa langkah, sesuai dengan perintah guru.

c. Melangkah ke belakang beberapa langkah, sesuai dengan perintah guru.

4. Kesadaran tempo.

Kesadaran tempo memungkinkan koordinasi gerakan antara mata dan anggota tubuh menjadi efisien. Istilah koordinasi mata dan tangan atau mata dan kaki merupakan ungkapan dari kesadaran tempo. Pengembangan kesadaran tempo berkenaan dengan proses belajar untuk menyelaraskan gerak dalam sebuah tata urut yang tepat. Lari berirama, menari, atau melakukan gerakan lainnya yang berirama sangat dibutuhkan untuk mengembangkan kesadaran tempo. Contoh gerakan: 
a. Mengayunkan kedua lengan ke depan dan ke belakang, dengan diiringi hitungan atau irama musik.

b. Mengayunkan kaki ke depan dan ke belakang secara bergantian, dengan diiringi hitungan atau irama musik.

\section{GANGGUAN PERSEPTUAL MOTORIK ANAK}

Perseptual motorik mengkaitkan antara fungsi kognitif dan kemampuan gerak. Menurut Clifton yang dikutip oleh Hari Amirullah Rachman (2003: 79) menjelaskan bahwa perseptual motorik terbentuk atas dua sistem, yaitu sistem persepsi dan sistem indera. Kedua sistem ini tidak dapat dipisahkan, hal ini dikarenakan seseorang tidak mungkin melakukan aktivitas gerak tanpa persepsi dan sebaliknya. Perseptual motorik memiliki peranan terhadap prestasi akademik. Lebih lanjut Thomas Lee yang dikutip oleh Hari Amirullah Rachman (2003: 80) menjelaskan pengaruh perseptual motorik pada fungsi kognitif diantaranya: (1) terdapat akibat dan keterkaitann langsung antara kemampuan perseptual motorik dan prestasi akademik dan (2) perseptual motorik melandasi kesiapan dan penampilan akademis. Hal ini dapat dicontohkan bahwa koordinasi mata tangan yang baik merupakan prasyarat untuk kemampuan menulis.

Perseptual motorik seseorang dibentuk oleh beberapa unsur, yaitu: kesadaran tubuh, kesadaran ruang, kesadaran arah, dan kesadaran tempo. Gangguan pada perseptual motorik dapat terjadi pada setiap anak. Beberapa contoh gangguan perseptual motorik pada anak di antaranya:

1. Tidak dapat mengidentifikasi bagian tubuh.

2. Tidak dapat meyentuh bagian-bagian tubuh atas perintah dari seorang guru.

3. Tidak dapat menirukan gerakan yang telah dicontohkan oleh guru.

4. Tidak dapat mengubah posisi dalam sebuah ruang.

5. Tidak dapat melakukan gerakan keseimbangan statis maupun dinamis.

\section{KARAKTERISTIK ANAK SEKOLAH DASAR}

Anak sekolah dasar termasuk dalam masa anak besar. Anak besar adalah anak yang berusia antara 6 sampai dengan 10 atau 12 tahun (Sugiyanto, 1991: 101). Perkembangan fisik yang terjadi pada masa ini menunjukkan adanya kecenderungan yang berbeda dibanding pada masa sebelumnya dan juga pada masa sesudahnya. Kecenderungan perbedaan ini terjadi dalam hal kepesatan dan pola pertumbuhan yang berkaitan dengan proporsi ukuran bagian-bagian tubuh.

Karakteristik anak usia sekolah dasar menurut Harsono (2000: 68-70) adalah sebagai berikut:

1. Periode umur 5-8 tahun.

a. Pertumbuhan tulang-tulang lambat.

b. Mudah terjadi kelainan postur tubuh.

c. Koordinasi gerak masih terlihat jelek atau kurang baik. 
d. Sagat aktif, main sampai penat, rentang perhatian atau konsentrasi sempit.

e. Dramatis, imajinatif, imitatif, peka terhadap suara-suara dan gerak ritmis.

f. Kreatif, rasa ingin tahu, senang menyelidiki dan belajar melalui aktivitas.

g. Senang membentuk kelompok-kelompok kecil, laki-laki dan perempuan mempunyai minat sama.

h. Mencari persétujuan orang dewasa (orang tua, guru, kakak dan lain-lain).

i. Mudah gembira karena pujian, tetapi mudah sedih karena dikritik.

2. Periode umur 9-11 tahun.

a. Dalam periode pertumbuhan yang tetap, otot-otot tumbuh cepat dan membutuhkan latihan, postur tubuh cenderung buruk, oleh karena itu dibutuhkan latihanlatihan pembentukan tubuh.

b. Penuh energi, akan tetapi mudah lelah.

c. Timbul minat untuk mahir dalam suatu keterampilan fisik tertentu dan permainanpermainan yang terorganisir, tetapi belum siap untuk mengerti peraturan yang rumit, rentang perhatian lebih lama.

d. Senang dan berani menantang aktivitas yang agak keras.

e. Lebih senang berkumpul dengan lawan sejenis dan sebaya.

f. Menyenangi aktivitas yang dramatis, kreatif, imajinatif, dan ritmis.

g. Minat untuk berprestasi individual, kompetitif, dan punya idola.

h. Saat yang baik untuk medidik moral dan perilaku sosial.

i. Membentuk kelompok-kelompok dan mencari persetujuan kelompok.

3. Periode umur 11-13 tahun.

a. Memasuki periode transisi dari anak ke pradewasa, perempuan biasanya lebih dewasa (mature) dari laki-laki, tapi laki-laki memiliki daya tahan dan kekuatan yang lebih.

b. Pertumbuhan tubuh yang cepat, tetapi kurang teratur, sering menyebabkan keseimbangan tubuh terganggu, karena gerakan-gerakannya cenderung kaku, dan dapat berlatih sampai penat.

c. Lebih mementingkan keberhasilan kelompok/tim, dibanding individu, lebih menyenangi permainan dan pertandingan yang menggunakan peraturan resmi dan lebih terorganisir, ingin diakui dan diterima sebagai anggota kelompok.

d. Adanya minat dalam aktivitas yang dapat meningkatkan kemampuan dan keterampilannya, mulai adanya minat untuk latihan fisik.

e. Senang berpartisipasi dalam kegiatan rekreasi aktif, perlu ada bimbingan dan pengawasan dalam pergaulannya dengan lawan jenis.

f. Kesadaran diri mulai tumbuh, demikian pula emosi, meskipun masih kurang terkontrol/terkendali, dan mencari persetujuan orang dewasa.

g. Peduli akan prosedur-prosedur demokratis dan perencanaan tim, semakin kurang dapat menerima sikap otoritas dan otokrasi orang lain. 


\section{MENDETEKSI GANGGUAN PERSEPTUAL MOTORIK}

Upaya untuk memengenali atau mendeteksi gangguan perseptual motorik pada anak, dapat dilakukan dengan tes perseptual motorik. Menurut Claudine Sherill (1993: 324-325), ada beberapa cara untuk mendeteksi gangguan perseptual motorik, di antaranya:

1. Mengidentifikasi atau mengenali bagian tubuh.

Tujuan: untuk pendengaran, ingatan dan sekuensi/penggiliran/urutan Cara:

a. Menyentuh bagian tubuh secara satu per satu yang disebutkan oleh guru.

b. Menyentuh dua bagian tubuh secara bersama yang disebutkan oleh guru.

c. Menyentuh lima bagian tubuh secara berurutan yang telah disebutkan oleh guru.

d. Melakukan semua gerakan di atas (dari a-c) dengan mata tertutup.

2. Menyentuh kanan-kiri bagian anggota badan yang berlawanan.

Tujuan: untuk pendengaran, ingatan, dan sekuensi/penggiliran/urutan Cara:

a. Menyentuh bagian tubuh dan permukaannya setelah guru selesai memberikan perintah, yang meliputi:

1) Menggunakan tangan kanan kemudian menyetuh bagian tubuh yang berada di sebelah kanan.

2) Menggunakan tangan kanan kemudian menyetuh bagian tubuh yang berada di sebelah kiri.

3) Menggunakan tangan kiri kemudian menyetuh bagian tubuh yang berada di sebelah kiri.

4) Menggunakan tangan kiri kemudian menyetuh bagian tubuh yang berada di sebelah kanan.

b. Memberikan kesempatan untuk menyentuh bagian tubuh temannya, anak akan mengikuti instruksi tanpa demonstrasi. Anak diharapkan melakukan:

1) Menggunakan tangan kanan untuk menyentuh bagian tubuh sebelah kanan temannya.

2) Menggunakan tangan kanan untuk menyentuh bagian tubuh sebelah kiri temannya.

3. Mengubah (berubah) posisi dalam suatu ruang.

Tujuan: untuk pendengaran, ingatan dan sekuensi/penggiliran/urutan Cara:

a. Memberikan kesempatan kepada anak untuk mengidentifikasi kedudukannya atau posisinya dengan objek atau benda yang tetap.

1) Berdiri di depan, belakang, samping kanan, dan di sebelah kiri sebuah kursi.

2) Berlari menuju base pertama dalam lapangan softball . 
3) Memperagakan posisi pemain bagian kanan, tengah dan kiri pada permainan softball.

4) Menempatkan posisi pada sebuah lingkaran, empat persegi panjang, dan bentuk yang lain di lantai.

5) Memanjat tali atau horisontal bar.

b. Memberi kesempatan kepada anak untuk mengikuti perintah, perintah verbal dalam pemanasan tanpa memberi contoh.

1) Melakukan gerakan posisi latihan dasar, seperti: balf squat, squat, kneel, long sitting, supine lying, book lying, book sitting, cross legge sitting.

2) Memperagakan perbedaan posisi kaki dalam merespon sebuah perintah: wide base, narrow base, square stance, colsed stance, dan open stance.

3) Menampilkan gerakan-gerakan tertentu sebanyak lima kali berturut-turut. Gunakan delapan hitungan untuk setiap gerakan dan ulangi kemudian berhenti dalam hitungan tertentu.

4. Melintasi garis tengah.

Tujuan: untuk pendengaran, ingatan dan sekuensi/penggiliran/urutan

Cara: memberi kesempatan pada anak untuk menggerakan lengan kanan menyilang garis tengah melalui perintah verbal tanpa memberi contoh.

a. Melempar bola ke arah diagonal

b. Menggelindingkan bola dengan posisi kaki berlawanan dengan tangan yang menggelindingkan.

c. Melakukan back hand tenis .

d. Menangkap pantulan bola dari tembok yang datang ke arah kiri badan.

e. Melontarkan bola tenis ke atas tegak (vertikal) di depan bahu kiri.

5. Meniru gerakan.

Tujuan: visualisasi, ingatan, dan pengurutan

Cara:

a. Memberi kesempatan kepada anak untuk meniru gerakan lengan dan tungkai yang dicontohkan.

1) Meniru gerakan bilateral

a) Meniru gerakan-gerakan lengan secara bersama atau sendiri, sementara tungkai tetap atau diam.

b) Menggerakan kaki secara bersama-sama atau sendiri, sementara lengan tetap atau diam.

c) Menggerakkan empat anggota tubuh secara bersama-sama atau sendirisendiri secara berurutan.

d) Mengkombinasikan tiga macam gerakan secara berurutan. 
2) Meniru gerakan-gerakan unilateral

a) Menggerakkan lengan kanan dan tungkai kanan secara sendiri-sendiri atau bersama-sama, sementara bagian kiri tetap.

b) Gerakan sebaliknya, dari gerakan di atas.

3) Meniru gerakan-gerakan menyilang ke samping.

a) Menggerakkan lengan kanan dan tungkai kiri secara sendiri-sendiri atau bersama-sama atau bersamaan secara berurutan, sementara yang lain tetap.

b) Melakukan gerakan sebalikanya, dari gerakan di atas.

b. Memberi kesempatan untuk meniru gerakan lengan dari guru tanpa intstruksi verbal.

1) Mulai dan berhenti ke dua lengan secara simultan.

2) Meniru secara benar enam dari sembilan gerakan.

c. Memberi kesempatan untuk meniru gerakan lengan dari guru yang memegang raket atau alat olahrga lainnya, tanpa instruksi verbal dengan benar dari sebelas gerakan.

6. Meniru gerakan olahraga

Tujuan: visualisasi, ingatan dan urutan

Cara: memberi kesempatan untuk meniru gerakan guru memanipulasi bola tenis, tanpa instruksi verbal.

a. Meniru gerakan guru dengan benar menggunakan lengan kanan seperti yang diperagakan guru.

b. Melempar bola ke atas setinggi/persis atau sama dengan yang diperagakan guru.

c. Memantulkan bola di depan, di samping dan variasinya.

d. Memantulkan bola dengan ketinggian, seperti yang diperagakan guru.

7. Jejak visual (visual tracking).

Tujuan: pengamatan visual, ingatan dan pengurutan

Cara:

a. Memberi kesempatan kepada anak untuk menggunakan matanya mengikuti jejak.

1) Mengikuti gerakan guru yang bergerak ke kiri atau ke kanan.

2) Mengikuti gerakan guru melakukan gerak berputar atau berkeliling.

3) Mengikuti gerakan guru secara acak dan berurutan.

b. Memberi kesempatan mengamati dan mengikuti benda-benda bergerak.

1) Mengikuti gerakan benda-benda yang bergerak yang dilempar guru sampai ke arah jatuhnya benda tersebut. 
2) Bergerak mengikuti benda-benda yang bergerak yang dilemparkan guru kemudian menangkapnya.

3) Bergerak mengikuti benda-benda yang bergerak yang dilemparkan guru kemudian memukulnya sebelum jatuh.

c. Memberi kesempatan untuk mengikuti jejak bola yang bergulir ke arahnya.

1) Menghentikan bola yang bergulir ke arah samping kanan.

2) Menghentikan bola yang bergulir ke arah tengah.

3) Menghentikan bola yang bergulir ke arah samping kiri.

8. Keseimbangan statis

Tujuan: visual atau auditori

Cara: memberi kesempatan untuk mengembangkan keseimbangan statis.

a. Berdiri dengan satu kaki selama 10 detik dengan mata tertutup.

b. Berdiri dengan satu kaki dengan ujung kakinya selama 10 detik.

c. Berdiri dengan satu kaki di atas benda seperti balok, batu, bata dan sebagainya.

d. Berdiri di atas satu lutut.

e. Berdiri dengan satu kaki dan kaki lainya squat.

f. Melakukan bead stand.

g. Mengulangi gerakan-gerakan keseimbangan di atas dengan mata tertutup.

9. Keseimbangan dinamis

Tujuan: visual atau auditori

Cara: memberi kesempatan anak untuk mengembangkan keseimbangan dinamis.

a. Berjalan di atas garis lurus.

b. Melompat ke belakang lima kali berturut-turut tanpa kehilangan keseimbangan.

c. Berjalan di atas balok titian dengan membawa beban di tangan kanan lima kilogram.

d. Berjalan dengan melakukan squat pada balok keseimbangan.

e. Berjalan dan berputar di atas balok titian sebanyak tiga kali putaran.

f. Melakukan loncatan seperti kangguru sambil memantul-mantulkan bola di antara kedua kakinya.

10. Dominasi lateral

Tujuan: visual dan auditori

Cara: memberi kesempatan mengeksplorasi gerakan yang memungkinkan dengan menggunakan raket, bad, tali dan lain sebagainya.

a. Dapat mendemonstrasikan beberapa keterampilan dengan menggunakan tangan yang lebih disukai daripada yang tidak disukai.

b. Dapat menampilkan kecenderungan lengan yang biasa digunakan secara konsisten daripada lengan lain. 


\section{KESIMPULAN}

Pendidikan jasmani merupakan belajar melalui aktivitas jasmani, yang didalamnya berisi tentang perseptual motorik. Perseptual motorik sangat penting dalam meningkatkan kemampuan gerak dan prestasi akademik siswa sekolah dasar. Mendeteksi gangguan perseptual motorik pada siswa, sangat penting untuk dilakukan oleh guru Penjas. Mendeteksi ganggừn perseptual motorik diharapkan dapat diketahuinya permasalahan atau gangguan perseptual motorik siswa sekolah dasar.

Upaya mengembangkan perseptual motorik pada siswa sekolah dasar harus dilakukan oleh seorang guru Penjas. Pengembangan perseptual motorik dapat dilakukan dalam bentuk gerakan-gerakan yang mengarah pada kemampuan untuk memahami tubuh, arah, ruang dan tempo. Semua aktivitas atau gerakan tersebut dapat dikemas dalam bentuk bermain.

\section{DAFTAR PUSTAKA}

BSNP. (2006). Standar Kompetensi dan Kompetensi Dasar Pendidikan Jasmani, Olabraga dan Kesehatan Sekolah Dasar dan Madrasah Ibtidaiyah. Jakarta: BSNP.

Claudine Sherill. (1993). Adapted Physical Activity, Recreation and Sport: Crossdisciplinary and Lifespan. Fourth Edition. United States of America: Wm. C. brown Communication, Inc.

Hari Amirullah Rachman (2003). Pengaruh Model Pembelajaran dan Kemampuan perseptual Motorik terhadap Keterampilan Bermain Softball Siswa Sekolab Dasar. Jurnal Nasional Pendidikan Jasmani dan Ilmu Keolahragaan. Jakarta: Proyek Pengembangan keserasian Kebijakan Olahraga, Direktorat Jenderal Olahraga, Depdiknas.

Harsono. (2000). Pemanduan dan Pembinaan Bakat Usia Dini. Jakarta: KONI.

Rusli Lutan. (2001). Asas-asas Pendidikan Jasmani: Pendekatan Pendidikan Gerak di Sekolah Dasar. Bandung: FPOK UPI.

Sugiyanto. (2007). Teori Kepelatiban Dasar. Jakarta: Kemenegpora. . (1991). Perkembangan Gerak. Jakarta: Depdikbud, Proyek Penataran Guru, Bagian Proyek Penataran Guru Penjas.

Yudha M. Saputra. (2001). Pembelajaran Atletik di Sekolah Dasar: Sebuah Pendekatan Pembinaan Gerak Dasar melalui Permainan. Bandung: FPOK UPI. 